Erratum

\title{
Erratum: Pan Y. et al. Cucumber Metallothionein-Like 2 (CsMTL2) Exhibits Metal-Binding Properties. Genes 2016, 7, 106
}

\section{Genes Editorial Office}

MDPI, St. Alban-Anlage 66, 4052 Basel, Switzerland; genes@mdpi.com; Tel.: +41-61-683-77-34

Academic Editor: Paolo Cinelli

Received: 10 January 2017; Accepted: 10 January 2017; Published: 12 January 2017

The authors wish to make the following correction to their paper [1]. The funding number in the Acknowledgement Section is wrong. The correct number is Chongqing Graduate Scientific Innovation project (Project No.: CYB2015065). The authors would like to apologize for any inconvenience caused. The change does not affect the scientific results. The manuscript will be updated and the original will remain online on the article webpage.

Conflicts of Interest: The authors declare no conflict of interest.

\section{Reference}

1. Pan, Y.; Pan, Y.; Zhai, J.; Xiong, Y.; Li, J.; Du, X.; Su, C.; Zhang, X. Cucumber Metallothionein-Like 2 (CsMTL2) Exhibits Metal-Binding Properties. Genes 2016, 7, 106. [CrossRef] [PubMed]

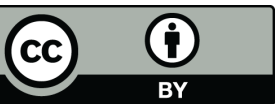

(C) 2017 by the author; licensee MDPI, Basel, Switzerland. This article is an open access article distributed under the terms and conditions of the Creative Commons Attribution (CC-BY) license (http://creativecommons.org/licenses/by/4.0/). 